\title{
Steering local housing production: evaluating the performance of governance structures
}

\author{
Edwin Buitelaar · George de Kam
}

Received: 4 September 2008/Accepted: 4 December 2008/Published online: 24 March 2009

(C) The Author(s) 2009. This article is published with open access at Springerlink.com

\begin{abstract}
This paper presents an analytical framework that allows us to evaluate the performance of dynamic governance structures. In housing development processes, governance structures-markets, hierarchies and network or relational structures-change as the process proceeds, and so do the goals that are set by all stakeholders, including local authorities. A framework for evaluation is set out that takes account of this temporal component. It is applied empirically to three case studies in the city of Arnhem (The Netherlands). The paper concludes that the effectiveness of steering housing production by local authorities depends on choosing appropriate governance structures, setting realistic goals, and a local authority that acts accordingly. Many of the choices with regard to goals and governance structures are not made autonomously but are structured by the spatial and institutional context in which they operate. A systematic evaluation of the performance of governance structures, within their context, could improve local government's capacity to steer housing production.
\end{abstract}

Keywords Governance structures - Housing development - Location development · Land policy

\section{Introduction}

In recent years, many have pointed to a shift from government to governance. This means that the dominant position of the state has changed, whereby the government agency is now co-producer of policy together with other public and private parties. This applies to

\section{E. Buitelaar $(\bowtie)$}

Netherlands Environmental Assessment Agency, Oranjebuitensingel 6, P.O. Box 30314, $2500 \mathrm{GH}$ The Hague, The Netherlands e-mail: edwin.buitelaar@pbl.nl

G. de Kam

Radboud University Nijmegen, Nijmegen, The Netherlands e-mail: g.dekam@fm.ru.nl 
Fig. 1 Housing production in The Netherlands, subdivided by commissioner, between 1950 and 2006. Source: CBS

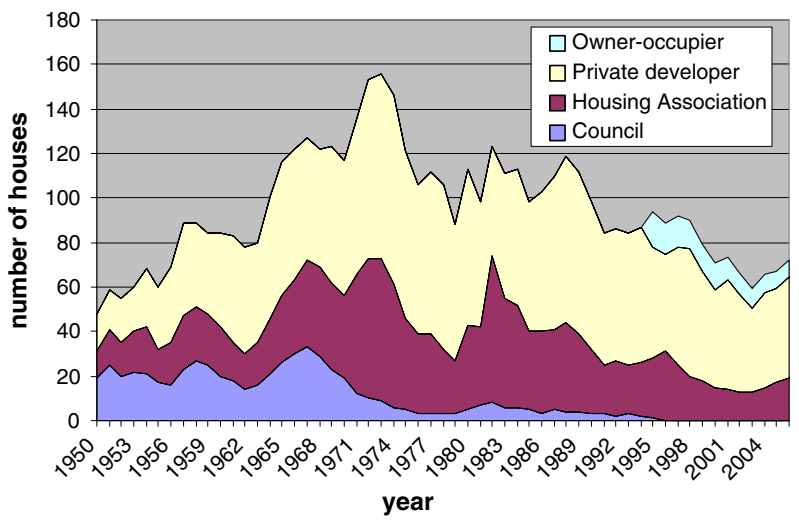

many policy areas, including housing and housing production (see Fig. 1). Due to various institutional changes (Korthals Altes 2007; De Kam 2007), Dutch housing associations no longer get grants for delivering affordable houses. They need to finance that segment out of their revolving fund or by building market-rate houses. Also the role of property developers has become much more prominent due to institutional changes (Groetelaers 2004). Municipalities used to have a monopoly on land, which they often sold off cheaply to housing associations. In addition, local councils even provided council houses themselves. Both positions have changed. Although municipalities often still pursue an active land policy, they have got company from developers that do the same. The provision of council houses has even disappeared completely (Fig. 1). For that reason, housing production has become more dependent on fluctuations on the housing market and in house prices (Korthals Altes 2007).

In general, the number of stakeholders in developing projects and providing houses has risen. Co-production is a logical result. Local governments have become more dependent on others for achieving their goals. An interesting question in this respect is whether and how governments can achieve their goals.

The aim of the paper is twofold. We want to set up a framework to analyse and evaluate what we call the steering capacity of governance structures to guide the building production - both quantitatively and qualitatively — in a direction that local governments want. The second aim is to reveal what really influences this capacity and the housing production at the project level by applying the framework empirically. This paper is mainly based on an empirical research project that was commissioned by the Dutch Ministry of Housing (Buitelaar et al. 2006) and therefore regards the Dutch context. What we do not intend is to provide definitive answers as to whether governance structures that steer housing production in The Netherlands are effective or not. That would require a different, more quantitative approach.

The paper is structured as follows. In the next section we will present a conceptual exploration of governance structures, drawing on the neo-institutional economic literature. Then a framework for evaluating the performance of governance structures is set up. This framework has been applied empirically to housing projects in the city of Arnhem, one on which we report in this paper. The paper concludes with a review of the performance of governance structures regarding housing in Dutch municipalities and with some comments on the evaluative approach. 


\section{Governance structures ${ }^{1}$}

We are mainly concerned with the institutions or rules that guide interaction between (and not within) organisations: the governance structures. This is a concept that originates from the field of new institutional economics. A governance structure is "an institutional framework in which the integrity of a transaction, or related set of transactions, is decided." (Williamson 1996: 11). Governance structures are therefore institutional arrangements that structure transactions between individuals and organisations. In new institutional economics, there is a distinction between governance structures and the institutional environment. The institutional environment is described as the legal, social and political rules that determine the context within which economic activity takes place (Williamson 1990). Williamson (1990) takes the institutional environment as a given. In the next section we choose not to do so but to look at how it affects the use of governance structures. In general, a distinction is made between market structures, hierarchical structures and a third form, which we call network or relational structures. These three ideal types will be distinguished below.

\subsection{Market}

Markets have been the subject of many articles and books and hence numerous definitions circulate in economics as well as in the social sciences in general. Although neo-classical economists cannot understand markets satisfactorily (see e.g. Coase 1988), due to a lack of attention for institutions and an overemphasis on explaining prices, this does not mean they have no definition of markets. However these definitions are often not institutional and regard the market as an assembly of buyers and sellers. Hirschman (1982: 1473), for instance, describes markets as a "large number of price-taking anonymous buyers and sellers supplied with perfect information [who] function without any prolonged human or social contract between the parties. Under perfect competition there is no room for bargaining, negotiation, remonstration or mutual adjustment and the various operators that contract together need not enter into recurrent or continuing relationships as a result of which they would get to know each other well."

Coase (1988: 7) focuses like most institutional economists on the institutional nature of markets: "Markets are institutions that exist to facilitate exchange, that is, they exist in order to reduce the cost of carrying out exchange transactions." Hodgson uses a similar definition: “... markets involve multiple exchanges, multiple buyers and multiple sellers, and thereby a degree of competition. A market is an institution in which a significant number of commodities of a particular, reasonably well-defined type are regularly exchanged." (Hodgson 2002: 44) What is not apparent in Coase's definition, and gets more attention in Hodgson's description, is the element of competition, which Hirschman emphasises as well. In a classical market, or thick market as Williamson (1996: 378) calls it, with very many buyers and sellers, there will be full competition. In cases of full competition, it is the price which brings demand and supply in equilibrium, and therewith governs the way people transact. Individual buyers and sellers have very little influence on these market prices.

This pure market form, in which personal contacts, identity or experience do not exist, is rare. The actions of individuals are embedded (Granovetter 1985) in cultural peculiarities. In addition, in many cases there are not multiple sellers, but oligopolies or monopolies. What makes pure markets almost non-existent in the case of land exchanges and land use

1 This section stems largely from Buitelaar (2007, chapter 2) 
planning is the nature of the good 'land'. This becomes clear when we look at a part of Hodgson's earlier mentioned definition: "a significant number of commodities" (Hodgson 2002: 44). But in the case of land, the word commodity hardly applies, since every piece of land is unique and immobile, which makes it irreplaceable by other tracts of land. In addition, the number of buyers and sellers is often limited. This leads to situations in which people have to rely on each other and exchange is co-ordinated by other mechanisms than price, like trust, as Needham and De Kam (2004) show for the exchanges of land for affordable housing between municipalities and housing associations.

It must be noted that there are also many other broader descriptions of markets, in which exchange can take many forms (Lindblom 2001). But for the sake of conceptual clarity, we prefer to use the relatively narrow description of the market, and we label voluntary exchanges by means other than the price mechanism, like for instance trust, as relational structures.

\subsection{Hierarchy}

Government agencies can and often do use authority to make sure that other organisations act in a desired way. This 'way' is often in the public interest, or at least it is assumed to be. In the literature hierarchical governance structures also apply to the private sector. Moreover, Coase's (1937) theory of the (private) firm was the starting point of the initial market-hierarchy dichotomy. We are concerned with the public sector and its steering capacity with regard to housing development. McGuinness (1991) gives a good definition of hierarchy, that applies to hierarchies in general. He regards hierarchies as "a class of governance whose distinguishing feature is that a resource owner accepts restrictions (often simply because he has to) on his sole rights to use his resources in whatever way he might choose. Within those bounds of some agreed domain, he allows his resources to be controlled by an authorised decision-making unit to which he might or might not belong." (McGuinness 1991: 74-75, parenthesis by authors).

It is also important to make a distinction between hierarchical structures between organisations and within, i.e. the firm or public agencies. Like Bromley (1989) and North (1990), we distinguish between institutions and organisations, regarding organisations as the 'players' that act within the institutions, 'the rules of the game'. With this distinction, firms and government agencies are treated as organisations and hierarchical governance structures, like zoning, as institutional arrangements between organisations. ${ }^{2}$

There are instruments that can be used within hierarchical governance. ${ }^{3}$ Zoning designates-some would say separates-land uses by restricting the exercise of property rights. Besides zoning there are also hierarchical tools that are used to take property rights. ${ }^{4}$ In The Netherlands, we should think of two policy instruments in particular. One is compulsory purchase which provides municipalities with the possibility to expropriate property owners, against complete compensation of income or capital loss. The other instrument is imposing a pre-emption right. This gives local authorities the right-for a designated area- to be the first buyer in case a property owner wants to sell his land.

\footnotetext{
2 There are also institutions within organisations.

3 Note that instruments and governance structures are intertwined but not the same. Governance structures tell something about the kind of relationship between actors, while instruments are the tools used within that relationship. It is through instruments that governance structures take effect.

4 Note that in the US zoning can also go as far as to constitute a (regulatory) taking.
} 


\subsection{Relational or network structures}

One of the main criticisms of transaction cost economics has long been the dichotomy that was set up between market and hierarchy (see e.g. Powell 1991; Thompson et al. 1991). It was Coase (1937) and Williamson (1975) who argued first that firms, i.e. hierarchies, and markets are alternative modes of governance. But since the 1980s, new institutional economists as well as other disciplines began to appreciate the importance of long-term relationships, reciprocity and collaboration, instead of the anonymous price mechanism in market structures or the use of authority in hierarchical structures. The most common term for this third category are networks (see Thompson et al. 1991; Thorelli 1986; Kickert et al. 1997). Hodgson speaks of relational structures (Hodgson 2002). We will use them interchangeably.

A network can be defined as a structure or an arrangement in which "two or more organisations (are) involved in long-term relationships." (Thorelli 1986: 37, parenthesis ours). In line with our discussion on hierarchies this definition focuses on the governance structures between organisations and not within; the following description seems to direct its attention to the latter. "When discussing networks, in the first instance at least, it is probably institutional arrangements like informal groups, mutual-aid organisations, smallscale and local institutional networks, cooperative forms of social existence, self-help groups, and so on that come immediately to mind." (Thompson 2003).

As a reaction to the critiques of the market-hierarchy distinction, it became popular to argue that the boundaries between them are fuzzy and indistinct. New ideas like 'quasimarkets', 'hybrid forms' (e.g. Williamson 1985); relational contracting (e.g. Richardson 1972; Williamson 1985) and 'internal markets' began to gain attention (Hodgson 2002). Some also position the term networks between markets and hierarchies (Thorelli 1986). This is the result of the observation made by many that a lot of transactions do not take place through markets (North 1977), nor through hierarchies. In every exchange there is some implicit or explicit legal contract, leading to an exchange of property rights. But not all exchanges have the competitive and transient features that market exchanges have (Hodgson 1988), nor the features of imposed rules or authority which hierarchies have. Reciprocity and collaboration are central features of these governance structures.

But arraying exchanges along a continuum with the market on one end and hierarchy on the other is misleading and does not do justice to the complexity of reality (Powell 1991). Hodgson (2002) argues that the existence of a third category should not imply that we do not need to conceptualise markets and hierarchies; the distinction between them is not blurred. Rather, there is (at least) a third distinct category: relational structures. But although markets, hierarchies and relational structures are distinct governance structures, they can nevertheless co-exist, as we will see in the case study. In the empirical part we will see that local governments participate in, or use, both hierarchical and relational structures.

Relational or network structures between organisations related to housing development can be found in all sorts of agreements like intention or development agreements between key stakeholders. But also more tacit long-term relationships like between housing associations and municipalities should be included. We will see examples of these in the empirical part.

\section{Evaluating the steering capacity}

The evaluation of the capacity of local governments to steer the housing production at specific locations differs from related capacity concepts like institutional capacity (Healey 1997) and governance capacity (Innes and Booher 2003). Where our analysis focuses on 
the issue of effectiveness of governance structures in the light of government goals, these two concepts-introduced by collaborative planning theorists-focus on the ability to act collectively, irrespective of the direction of those actions. The goals and the products are seen as endogenous to the collaborative process. Setting goals is a collective process, just like implementing them. The institutional and governance capacity is assumed to be high if stakeholders are able to act collectively, allowing a diversity of opinions to be raised, and if this collective is able to respond accurately to a rapidly changing world. What comes out of the process is 'good' when it is produced collectively. This is a valuable and worthwhile perspective, albeit not uncontested (Neuman 2000).

Because of collective action problems we have a government. Our normative stance is that the interest and the position of the government is not just like any other stakeholder's. Therefore, we look at governance structures, and their effectiveness, from the perspective of local governments and the goals they set for themselves. We use the concept steering capacity for that purpose. It is regarded here as the capacity to steer the actions of other agents (like housing associations and property developers) in a particular, preferred-by the one who tries to steer-direction. What the direction is, is not always known in advance but articulated during the process, in interaction with others. We do not evaluate whether strategic housing policy or spatial planning is effective (see e.g. Mastop and Faludi 1997), since that assumes a clear division between policy-making and goal-setting on the one hand and implementation on the other. The problem with evaluating effectiveness is to separate ends and means entirely. As Lindblom (1959) argues: “... one simultaneously chooses a policy to attain certain objectives and chooses the objectives themselves." We will pay attention to this reciprocity, which is conceptualised in Fig. 2. The governance structures through which housing development is co-ordinated depend on the goals set by the local government, but also on the goals and actions of other actors that are connected to the local government through some form of governance structure. These actors are influenced, or maybe even steered, by the governance structure at the same time. But the goals local governments set are not chosen randomly, they are derived from the (im)possibilities offered by other agents and the governance structures at hand. All the decisions are not taken autonomously but take place within an institutional context. What this makes clear is that an evaluation of governance structures alone does not make sense. The way people deal with them, and the institutional context within which they do that, is indispensably related to those governance structures (Giddens 1984).

The way these factors interact does not remain the same throughout the whole development process. To unravel these interdependencies, we have divided three development projects in steering stages (Buitelaar et al. 2006). Each of these is a stage in the development process that is ended and marked by a clear decision, whether or not in a favourable direction. These stages are not necessarily sequential but can be partly parallel. Per stage, the following questions have been addressed.

1. What were the municipal goals preceding the steering stage?

2. Through which governance structure are the goals pursued?

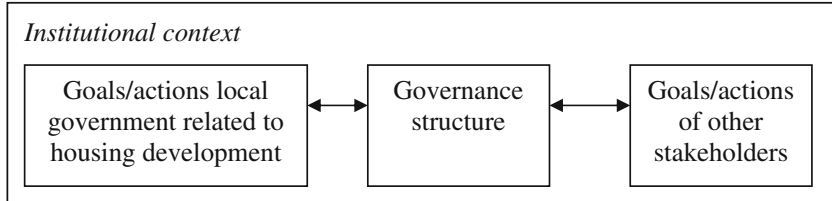

Fig. 2 Analytical framework 
Governance structures, instruments and goals are not chosen out of an infinite range of alternatives. Their selection is strongly affected by the institutional context and by the actions of other agents. Land ownership constraints, legislation and informal rules and practises all play their role in 'choosing' governance structures and goals. They therefore also affect the steering capacity.

3. Why were the goals and governance structures chosen that have been chosen, and were there any alternatives?

Although goals and means are often simultaneously chosen this does not automatically lead to effectiveness. There is much uncertainty about future events. And therefore municipalities can do no more than make assumptions about the steering capacity of governance structures.

4. What are the assumptions behind the working of the governance structure?

Then it is important to look at the governance structures in action: the process.

5. How did the steering process go?

The above questions all regard the steering capacity within a given institutional context. The context affects the governance structures. Would the governance structure that is in place be different under a different context? For instance, would there be a difference if new policy instruments were available?

6. Would there have been a wish for new policy instruments at the beginning of the steering stage if those would have been available, and have concessions been made to the goals and ambitions because of a lack of those instruments?

These questions were the focal point in the empirical research. We held interviews with the key stakeholders (eight interviewees) and did extensive archival research on the project files that have been made available to us by the municipality of Arnhem.

\section{Empirical application}

The empirical part of this paper reports on only one of the three case studies, because our aim is to illustrate the application of the framework. Applying it to all cases would stretch the paper beyond the size that is appropriate for an article.

De Hofpoort is located close to the railway station in the centre of the city of Arnhem, and consists of a slightly sloping site of about 1.2 ha. Before the new development, the area was designated in the land use plan for housing, retail, commercial enterprises and public amenities. The main initial occupation of the land was the supermarket, owned by a local real estate developer and let to a national chain of supermarkets. Apart from that, the municipality had land on the site. This made the municipality and the real estate developer interdependent which positioned them mostly in relational or network structures.

Hofpoort became a potential site for redevelopment of housing when the national government adopted a scheme of large-scale and long-term agreements with local authorities, aiming at the simultaneous development of greenfield as well as inner-city areas. Although Hofpoort had already turned out to be an expensive site (because of its slope and soil contamination), it got higher priority in the early 1990s. That was because other developments in the general agreement were confronted with serious delay, jeopardising the subsidies the national government had made dependent on a certain amount of 
housing construction. Therefore, the city of Arnhem decided to make available two million Euros for subsidising the site, on the condition that this would be paid only when the building permit had been granted.

In the development process of the project the following four steering stages can be identified. Within these stages we see relational and hierarchical structures and combinations of both. During the first stage the municipality and the real estate developer committed themselves to the re-development of the site and made their first deals about their roles and about the transactions of land. This stage was concluded by signing the intention agreement. At the second stage parties started the actual planning process; this is when municipal goals shifted from process-related goals to substantial goals. The local authority used the intention agreement to steer the development. This stage ended when the City Council refused to submit the plan for formal approval, because there were strong objections from the neighbouring residents. In the third stage the planning started anew, in a more participatory way and with adapted municipal goals. This stage was concluded by formal approval of the plan for the site. At the fourth and last stage, parties focussed on the actual realisation, laying down their agreement in a detailed contract and in specifications for the public amenities. We will now apply our framework to analyse these successive stages.

Stage 1: The initiative and the initial agreement

This stage is entered because the local authority has given higher priority to developing the site in order to meet the terms of its city-wide construction agreements with the national government.

\section{Municipal goals set for this stage}

The city wanted to come to an agreement for redevelopment of the site, including the relocation of the supermarket within a reasonable period of time. It wanted a plan conforming to its conditions with respect to finance, housing, city planning and preservation of existing monuments. The plan should consist of 100 dwellings in an architectural design that fits within the environment, preferably with $30 \%$ social housing in line with the city's strategic housing policy. The city was willing to grant a subsidy to a maximum of two million euros, and in return for that it wanted to have a say in the choice of the architect of the plan. And finally the city wanted to agree upon the roles its private partners would play in the planning and development process. What the city had in mind was to develop the land itself in order to control the quality of land readjustment, to engage its own municipal engineering department and to fully recoup all of the costs of land development.

\section{Use of governance structures and instruments}

In this stage both parties were related to each other in network structures with hierarchical measures in the background. The first important instrument the municipality used was the subsidy, which would be granted on the condition that the developer would actually start construction. The second instrument was based on the fact that in order to achieve his goals, the developer would need a revision of the land use plan. That enabled the local authority to steer by setting the conditions of this revision. And the agreement was to be concluded in a letter of intent, largely based on mutual trust. 
3 The reasons behind the choice of goals and the way the governance structures were set up

The Hofpoort site was given priority because the local authority knew that private owners were willing to co-operate in development. The other municipal goals can be seen as elements of the local planning policy and planning culture. The instruments the government chose were vital for the property developer. Subsidies were necessary and used. And the public land use plan had to be revised. So the choice of instruments was rather obvious, placing the municipality in a relatively strong position in the planning process.

\section{Assumptions regarding the functioning of the governance structure}

The city assumed that its instruments would be sufficient to come to an agreement by mutual arrangement with its private partners. On the basis of this agreement a plan would be designed in accordance with the municipal conditions.

\section{The outcome of the process}

Parties were relatively content with the process at this stage. Contrary to its original intentions, the local authority decided to refrain from readjusting the land itself. The city gave in to the wish of the private developer, because it wanted to carry out the land readjustment itself. So it agreed on private land readjustment, using its legal public power to specify the desired quality of public amenities to be realised by the private developer. All other municipal goals have been achieved by the terms of the contract, the authority to review building plans and grant building permits, and by having a say in the choice of the architect. The number of dwellings in that version of the plan was 95, and the developer would pay for the municipal planning costs, whereas the city would contribute by using its subsidy. Due to reluctance on the part of the supermarket-for reasons not related to the redevelopment of the Hofpoort site-it took several years before the contract could be signed.

\section{Would other steering instruments have been needed?}

The negotiations 'under the shadow of law' (Scharpf 1997), in combination with the subsidy, have worked out well for achieving the municipal goals at this stage. The delay in signing the contract has been caused by external factors. Looking back at this first steering stage, we may conclude that the city has been able to maintain most of its public goals related to housing and inner-city development by using planning law, a private contract and a (conditional) subsidy. The aim to pursue an active land policy-and act as a private enterprise - has been abandoned, since this was a condition set by the developer.

Stage 2: The first plan

After the first stage was completed with a contract of intent, the parties started drawing up plans for redeveloping the Hofpoort site. 
1 Municipal goals set for this stage

The municipal goal for this stage was to have a plan that would conform to the conditions of the contract while achieving the goals it had with regard to housing, urban design and preservation of monuments. Parties agreed to have the planning process follow the lines of 'design-announce-defend', which means that the plan-making was the sole terrain of professionals that had little interaction with the community before finalising the design.

\section{Use of governance structures and instruments}

Again, at this stage there was a combination of hierarchical and network structures. The instruments used at this point are the letter of intent in combination with the legal power to withhold building permission of construction plans that do not conform to the land use plan (in revision). The contract stated that the city would take part in the selection of the architect, and that it would have the right to approve the plans for urban design and layout. These rights could not have been grounded in public planning law alone, and it is against this background that the local authority intended to achieve its goals by negotiation with the developer.

3 The reasons behind the choice of goals and the way the governance structures were set up

The city had few other options because it had committed itself to the letter of intent. At this stage the 'exploitation' of the developers' need to have the land use plan revised has lost most of its potential for municipal steering, because the city had stated that it would co-operate in changing the land use plan for the site. There would have been alternatives for the planning procedure however, such as a more participatory process. But the city preferred to prepare a feasible plan with its professional partner, probably because it was found less risky.

\section{Assumptions regarding the functioning of the governance structure}

At this second stage two different sets of assumptions were important. The local authority assumed that its legal planning powers in combination with the contract would offer sufficient opportunities to steer the outcome of the planning process, and that it would be possible to speed up this process by good professional preparation. But it also assumed that the neighbouring residents would be content with this outcome because it would replace the supermarket and the nuisances it brought by new housing.

\section{The outcome of the process}

The selection of an architect went smoothly. The architect produced a plan that met all municipal requirements. At its first public presentation, this plan met with much protest from the neighbouring residents, mainly because of its massive character. Although it appeared that these objections could not be taken away by subsequent adaptations of the plan, the municipal administration-the alderman-nevertheless decided to start the formal land use planning procedure that would enable the execution of this plan. This procedure was then blocked in its very first stage by the city council planning 
committee, which was responsive to the public objection. As a consequence, the process of developing a plan for the Hofpoort site had to start all over again.

\section{Would other steering instruments have been needed?}

Obviously, the disappointing outcome of this second stage is not due to the lack of steering capacity of the governance structures and the instruments that have been applied. Rather, it seems to have to do with the implementation of the governance structure rather than with its defectiveness. The city administration and its planners seem to have miscalculated the residents' opposition, probably because they wanted a quick deal in order to be able to meet the targets of new housing construction-and the money attached to them - set by the national government.

Stage 3: The second plan

At this third stage of the planning process the essential goal is to design a plan that will get sufficient civil support to convince the city Council to approve it, while at the same time retaining as many goals of the set in the previous stages of the process as possible.

\section{Municipal goals set for this stage}

The municipality wanted to arrive at a feasible plan for housing at the Hofpoort site in concert with the residents and the developer, respecting the municipal policy of preservation of monuments at the site. The city wanted to start up a dialogue with the residents in order to take away the objections to the plan. And it was willing to 'buy consent' by selling some land to adjacent residents for the extension of their private backyards.

\section{Use of governance structures and instruments}

In this stage a network structure was used in which participatory planning played an important role to get support for a new plan. Although the municipality did not give away its power of final approval of the plan, it tried to achieve its own goals in first instance by active involvement in the meetings with residents and the developer, so as to minimise the risk of losing civil support (again). As a consequence, it had to accept the possibility that not all municipal goals regarding the content of the plan would be achieved.

3 The reasons behind the choice of goals and the way the governance structures were set up

The local authority had few other options, because its own planning committee had rejected the first plan for reasons of insufficient communication with the public. An external factor was that some pressure was put on the process because the supermarket was about to move out of the area, so that land transactions and the related costs would come into play. 


\section{Assumptions regarding the functioning of the governance structure}

The city assumed that this participatory process would result in a widely supported plan, and it realised that it might have to pay a price for that with respect to the content of the plan. It assumed that a supported plan would be more feasible, and that it would pass the formal procedures more quickly and at lower costs in terms of transaction costs and claims for planning compensation.

\section{The outcome of the process}

The developer decided to invite a new architect who was trusted by the residents to design the new plan, and the municipality commissioned a new project manager as well. The participatory planning approach resulted in a draught plan that was supported by the residents. Based on this draught plan, the formal procedure for revision of the land use plan was run successfully. In order to make this plan feasible, the local authority had to accept that the density would go down from more than one hundred to 87 dwellings. The plan also compromised on the conservation of several monumental vaults on the site. And it turned out that the residents' participation in the planning process did not prevent them from claiming planning compensation for the loss of property value. Two of these claims are being dealt with by the court.

\section{Would another steering instrument have been needed?}

In this stage it is not the nature of the steering instruments that changes but the way the instruments are applied by the local authority, shifting to a more participatory planning process. This is due to a change in planning approach as well as the 'sacrifice' of the original goal for preserving the monumental vaults on the site, and a reduction in the number of dwellings to be constructed.

Stage 4: The realisation of the plan and the lay-out of the public space

The land use plan and the general design of the area having been approved, in the final stage the local authority and the developer had to agree upon the actual construction of the dwellings and the public amenities of the Hofpoort site.

\section{Municipal goals set for this stage}

The city wanted the construction of dwellings and public amenities to occur according to the plans that had been approved. To achieve this it would sell its properties on the site to the developer, and after completion of the plan it would get back the public spaces in freehold without charges, designed according to the specifications it has set. Another goal was to limit municipal expenses on planning costs, which had already exceeded the budget reserved for that. And finally, the city wanted to conclude its transactions of land for the extension of backyards with some adjacent residents.

\section{Use of governance structures and instruments}

The city wanted the construction of dwellings and public amenities to occur according to the plans that had been approved. To achieve this it would sell its properties on the site to the developer, and after completion of the plan it would get back the public spaces in 
freehold without charges, designed according to the specifications it has set. Another goal was to limit municipal expenses on planning costs, which had already exceeded the budget reserved for that. And finally, the city wanted to conclude its transactions of land for the extension of backyards with some adjacent residents.

3 The reasons behind the choice of goals and the way the governance structures were set up

At this stage, negotiation in a network structure was used to reach the desired quality level for the public space. The most important instrument at this stage was the letter of intent, containing the basic agreements with the developer. These had to be worked out in a more detailed agreement. In these negotiations the city-contrarily to the first stage of the process - could not exert pressure with its subsidy, because this had already been granted to the land owner as a contribution to the costs of decontamination of the polluted soil on the site. And because the land use plan had been formally approved, the city could not threaten to withhold the building permit either-as it could have done in previous stages. So the only means of power the local authority had at this stage was its right to refuse to take back the public spaces in case these had not been adjusted to the required municipal specifications.

\section{Assumptions regarding the functioning of the governance structure}

The city assumed that the initial contract and the deal with the adjacent residents would suffice to come to final agreements with the developer.

\section{The outcome of the process}

The local authority put pressure on the developer to sell the land for extension of the residents' backyards at the same price the city itself would charge for similar tracts of land. As a result a better lay-out of the site could be realised. The details of the design of public spaces and amenities were less easily agreed upon, mainly because the initial contract had not been specific enough in this respect. The city repeatedly rejected the developer's infrastructural plans. A final matter of negotiation was the municipal goal to have a public playground on the site. Many of the adjacent residents were opposed to this because it would be situated behind their houses and they feared that this would lead to a socially unsafe living environment. By way of compromise it was then agreed that the playground would become gated, owned and managed by the homeowners association.

\section{Would other steering instruments have been needed?}

The municipal goals for this stage have been achieved within the governance structure and with the instruments used. The fact that the property rights of the playground were transferred to the residents is a political choice rather than a matter of failing instruments for steering. The problems in the process of detailing the public space were not due to shortcomings in the instruments either, because the local authority used the available instrument of withholding its approval effectively. But the process could have run more smoothly — and at lower costs - if parties had made up a more detailed initial contract related to this issue. 


\section{Conclusions}

One of the motives for our empirical research was the doubt that has risen about the effectiveness of steering housing production, particularly by using hierarchical means of governance (De Kam 1998). The case studies showed that the city of Arnhem does use its hierarchical modes of governance, but it seldom does so in a direct way. The hierarchical way of obtaining property rights by expropriation is not commonly chosen. That is because it requires a lot of determination and professionalism on the part of the administration. But it is also because developers can defy expropriation on the grounds that they are willing and able to realise the project according to municipal specifications.

Most of the public goals have been achieved in the shadow of hierarchy (Scharpf 1997), and by withholding approval or postponing the formal decision on the land use plan because that would give the developer the right to build. Relational governance structures are very important in combination with those hierarchical structures for steering local housing production. Given a specific setting of property rights, the local authority often will have to negotiate a contract with the private parties who have an interest in the site. Several types of contracts have been developed in practise, ranging from a more or less passive role, to full participation in a joint land development corporation with the developers.

The less hierarchical the governance structure, the less the outcome can be evaluated against a set of detailed pre-determined goals. The case studies have shown some of the factors that make the definition of goals a dynamic element of the planning process as a whole. It is not only the negotiations with the parties involved in the contract, but also the dynamics of broader policy goals as well as the interaction with residents and other stakeholders that contribute to shifting goals. In trying to achieve these goals, the local authority uses elements of its hierarchical potential all the way through the subsequent stages of the relational contracting process.

\subsection{The role of actors}

Governance structures and the use of instruments cannot be evaluated on their own. Much of the steering capacity will depend on the way these instruments are actually applied and on the goals actors set. Effectiveness requires not only the efforts of project managers but also an univocal approach of the different municipal departments involved in a project. And it calls for consistency in policy of both politics and bureaucracy. On top of several examples of failing internal municipal co-ordination-including the co-ordination between administration and council as in the Hofpoort case-we have also observed the negative effects of a certain path-dependency in the interventions by the administration: things that have gone wrong in earlier projects tend to be over-corrected in the next project at the expense of other issues that are equally important to achieve the desired outcome.

In the case studies we also saw that goals are sometimes moving targets; they change now and again. Many changes in goals were not so much the result of insufficient use or lack of instruments, but rather of deliberate choices. An example is dropping the number of houses to 87 for the benefit of the neighbourhood. In these circumstances, there is no lack of steering capacity of governance. Spatial planning is the art of trading off interests and land use claims. Housing production (in quantitative terms) is not the only interest. 


\subsection{The institutional environment}

The actions of agents cannot be understood without paying attention to the context within which they operate. For instance, actors have to deal with property market and budgetary constraints. This means that the efforts of steering housing production should be understood in a broad spatial and institutional context. Spatial relationships become important when functions-like the supermarket in the Hofpoort case-have to be relocated, when complex functions have to be integrated, when sites are part of larger spatial plans, or when co-ordination of housing production at different sites is at stake. The broader institutional context in which (the steering of) a project should be understood encompasses not only the overall dynamics of municipal policy but also many aspects of the relations between the municipality and other parties involved. In the Hofpoort case the selection of architects was a typical example of the influence of existing relations. In the other two cases the existing long-term relationship between the city and some of the local housing associations had a distinct influence on the outcome of the steering process. And the city of Arnhemlike many others-turned out to be most reluctant to use its instrument of expropriation because it values a good relationship with private property owners highly.

All these examples of institutions indicate to us that there is little room for the 'voluntarism' that some authors have observed in theories of governance in policy networks that take little notice of institutions and habitual behaviour (Van Tatenhove and Leroy 1995).

\subsection{The value of the analytical framework}

The analytical framework has enabled us to identify separate stages in the planning process and to systematically review the goals and instruments chosen, as well as the outcome of the steering process at these stages. At first glance we might have concluded that the development of the Hofpoort site has not been effectively steered. The intended number of houses has been reduced, monumental vaults have not been preserved, the active municipal role in land readjustment was given up, and the planning process took many years. Our analysis, however, has clarified that this 'failure' is due to a complex set of reasons related to the subsequent stages of the process. The fact that the city had set goals it could not get political support for has to do as much with the effectiveness of governance structures as with professionalism in planning, conflicting interests, changing goals and so on.

Understanding a lagging building production goes beyond the simple answers that are sometimes given. It requires a thorough insight into dynamic micro-level structures at the level of the location. The housing production target $-80,000-100,000$ houses a year- that the central government sets should take into account—at least much more-what happens 'on the ground'.

Open Access This article is distributed under the terms of the Creative Commons Attribution Noncommercial License which permits any noncommercial use, distribution, and reproduction in any medium, provided the original author(s) and source are credited.

\section{References}

Bromley, D. W. (1989). Economic interests and institutions. Oxford: Blackwell.

Buitelaar, E. (2007). The cost of land use decisions: Applying transaction cost economics to planning \& development. Oxford: Blackwell. 
Buitelaar, E., Mertens, H., Needham, B., \& De Kam, G. (2006). Sturend vermogen en woningbouw: een onderzoek naar het vermogen van gemeenten om te sturen bij de ontwikkeling van woningbouwlocaties, [Steering capacity and housing: analysing the municipal capacity to steer housing development]. Den Haag/Utrecht: DGW/NETHUR.

Coase, R. H. (1937). The nature of the firm. Economica, 4, 386-405.

Coase, R. H. (Ed.). (1988). The firm, the market and the law. Chicago: The University of Chicago Press.

De Kam, G. (1998). Value for money: Quality and price of land for social housing in The Netherlands. Netherlands Journal of Housing and the Built Environment, 4, 453-475.

De Kam, G. (2007). Social entrepreneurs in the land market: Dutch housing associations' strategic response to institutional change. Paper presented at the ENHR conference 25-28 June 2007 in Rotterdam.

Giddens, A. (1984). The constitution of society. Cambridge: Polity Press.

Granovetter, M. (1985). Economic action and social structure: The problem of embeddedness. American Journal of Sociology, 91, 481-510.

Groetelaers, D. A. (2004). Instrumenten locatieontwikkeling: sturingsmogelijkheden voor gemeenten in een veranderde marktsituatie, [Instruments for location development: local possibilities to steer in a changing market]. Delft: DUP Science.

Healey, P. (1997). Collaborative planning: Shaping places in fragmented societies. Basingstoke: Macmillan.

Hirschman, A. O. (1982). Rival interpretations of market society: civilizing, destructive, or feeble. Journal of Economic Literature, 20, 1463-1484.

Hodgson, G. M. (1988). Economics and institutions: A manifesto for a modern institutional economics. Cambridge/Philadelphia: Polity Press/University of Pennsylvania Press.

Hodgson, G. M. (2002). The legal nature of the firm and the myth of the firm-market hybrid. International Journal of the Economics of Business, 1, 37-60.

Innes, J. E., \& Booher, D. E. (2003). Collaborative policymaking: Governance through dialogue. In M. Hajer \& H. Wagenaar (Eds.), Deliberative policy analysis, understanding governance in the network society. Cambridge: Cambridge University Press.

Kickert, W. J. M., Klijn, E.-H., \& Koppenjan, J. F. M. (Eds.). (1997). Managing complex networks: Strategies for the public sector. London: Sage Publications.

Korthals Altes, W. K. (2007). The impact of abolishing social-housing grants on the compact-city policy of Dutch municipalities. Environment and Planning A, 39, 1497-1512.

Lindblom, C. E. (1959). The science of muddling through. Public Administrator Review, 19, 78-88.

Lindblom, C. E. (2001). The market system. What it is, how it works and what to make of it. New Haven/ London: Yale University Press.

Mastop, J. M., \& Faludi, A. K. F. (1997). Evaluation of strategic plans: The performance principle. Environment and Planning B: Planning and Design, 6, 815-832.

McGuinness, T. (1991). Markets and managerial hierarchies. In J. F. G. Thompson, R. Levacic, \& J. Mitchell (Eds.), Markets, networks \& hierarchies: The coordination of social life. London: Sage Publications.

Needham, B., \& De Kam, G. (2004). Understanding how land is transacted: Markets, rules and networks, as illustrated by housing associations. Urban Studies, 10, 2061-2076.

Neuman, M. (2000). Communicate this! Does consensus lead to advocacy and pluralism. Journal of Planning Education and Research, 19, 343-350.

North, D. C. (1977). Markets and other allocation systems in history: the challenge of Karl Polanyi. Journal of European Economic History, 6, 703-716.

North, D. C. (1990). Institutions, institutional change and economic performance. New York: Cambridge University Press.

Powell, W. W. (1991). Neither market nor hierarchy: Network forms of organization. In G. Thompson, J. Frances, R. Levacic, \& J. Mitchell (Eds.), Markets, hierarchies \& networks: The coordination of social life (pp. 265-276). London: Sage Publications.

Richardson, G. B. (1972). The organisation of industry. Economic Journal, 82, 883-896.

Scharpf, F. (1997). Games real actors play: Actor-centered institutionalism in policy research. Boulder, CO: Westview Press.

Thompson, G. F. (2003). Between markets \& hierarchies: The logic and limits of network forms of organization. New York: Oxford University Press.

Thompson, G., Frances, J., Levacic, R., \& Mitchell, J. (Eds.). (1991). Markets, hierarchies \& networks: The coordination of social life. London: Sage.

Thorelli, H. B. (1986). Networks: Between markets and hierarchies. Strategic Management Journal, 1 , $37-51$. 
Van Tatenhove, J., \& Leroy, P. (1995). Beleidsnetwerken: een kritische analyse. Beleidswetenschap, 2, $128-145$.

Williamson, O. E. (1975). Markets and hierarchies. New York: Free Press.

Williamson, O. E. (1985). The economic institutions of capitalism: Firms, markets, relational contracting. New York: Free Press.

Williamson, O. E. (1990). Chester Barnard and the incipient science of organization. In O. E. Williamson (Ed.), Organization theory: From Chester Barnard to the present and beyond (pp. 172-206). New York: Oxford University Press.

Williamson, O. E. (1996). The mechanisms of governance. New York: Oxford University Press. 